\title{
Mid-Luteal 17-OH Progesterone Levels in 614 Women Undergoing IVF-Treatment and Fresh Embryo Transfer-Daytime Variation and Impact on Live Birth Rates
}

\begin{abstract}
Lise Haaber Thomsen ${ }^{1,2 *}$, Peter Humaidan ${ }^{1,2}$, Karin Erb ${ }^{3,4}$, Martin Overgaard ${ }^{5}$, Claus Yding Andersen ${ }^{6}$ and Ulrik Schiøler Kesmodel ${ }^{7,8}$
\end{abstract}

${ }^{1}$ The Fertility Clinic, Skive Regional Hospital, Skive, Denmark, ${ }^{2}$ Department of Clinical Medicine, Aarhus University, Aarhus, Denmark, ${ }^{3}$ The Fertility Clinic, Odense University Hospital, Odense, Denmark, ${ }^{4}$ OPEN, Odense Patient Data Explorative Network, Odense University Hospital, Odense, Denmark, ${ }^{5}$ Department of Biochemistry, Odense University Hospital, Odense, Denmark, ${ }^{6}$ Laboratory of Reproductive Biology, The Juliane Marie Centre for Women, Children and Reproduction, University Hospital of Copenhagen, University of Copenhagen, Copenhagen, Denmark, ${ }^{7}$ The Fertility Clinic, Herlev University Hospital, Herlev, Denmark, ${ }^{8}$ Department of Clinical Medicine, University of Copenhagen, Copenhagen, Denmark

Introduction: Corpus luteum $(\mathrm{CL})$ produces progesterone $\left(\mathrm{P}_{4}\right)$ and 17-OH progesterone (17-OH $\mathrm{P}_{4}$ ) during the luteal phase. Contrary to $\mathrm{P}_{4}, 17-\mathrm{OH} \mathrm{P}_{4}$ is not supplied as part of the luteal phase support following IVF-treatment. Therefore, measuring endogenous serum 17- $\mathrm{OH} \mathrm{P}_{4}$ levels may more accurately reflect the $\mathrm{CL}$ function compared to monitoring serum $\mathrm{P}_{4}$ concentrations.

Objective: To explore the correlation between mid-luteal serum 17-OH $\mathrm{P}_{4}$ levels and live birth rates and to explore the possible daytime variations in mid-luteal serum $17-\mathrm{OH} \mathrm{P}_{4}$

Design: Prospective cohort study.

Patients: 614 women undergoing IVF-treatment and fresh embryo transfer.

Intervention: All patients had serum 17- $\mathrm{OH} \mathrm{P}_{4}$ measured 7 days after oocyte pick-up $(\mathrm{OPU}+7)$. Furthermore, on OPU+7, seven patients underwent repeated blood sampling during daytime to clarify the endogenous daytime secretory pattern of $17-\mathrm{OH} \mathrm{P}$.

Outcome measure: Live birth rate.

Secondary outcome measure: Daytime variation in serum 17-OH $\mathrm{P}_{4}$ levels.

Results: The highest chance of a live birth was seen with mid-luteal 17-OH $\mathrm{P}_{4}$ between 6.0 and $14.0 \mathrm{nmol} / \mathrm{l}$. The chance of a live birth was reduced below (RD $-10 \%, p=$ 0.07), but also above the optimal range for $17-\mathrm{OH} \mathrm{P}_{4}(\mathrm{RD}-12 \%, p=0.04)$. Patients with diminished $\mathrm{CL}$-function (17- $\left.\mathrm{OH} \mathrm{P}_{4}<6 \mathrm{nmol} / \mathrm{l}\right)$ displayed clinically stable $17-\mathrm{OH} \mathrm{P}_{4}$ values, whereas patients with $17-\mathrm{OH} \mathrm{P}_{4}$ levels $>6 \mathrm{nmol} / \mathrm{l}$ showed random $17-\mathrm{OH} \mathrm{P}_{4}$ fluctuations during daytime.

Conclusion: The association between 17- $\mathrm{OH} \mathrm{P} \mathrm{P}_{4}$ and reproductive outcomes is nonlinear, and the negative effect of excessive CL-secretion seems to be just as strong as the negative effect of a reduced CL-function during the peri-implantation period.

Keywords: 17-OH progesterone, progesterone, IVF, live birth, daytime variation 


\section{INTRODUCTION}

Following ovulation, the human corpus luteum (CL) produces progesterone $\left(\mathrm{P}_{4}\right)$ and $17-\mathrm{OH}$ progesterone $\left(17-\mathrm{OH} \mathrm{P}_{4}\right)$ upon stimulation with luteinizing hormone (LH) or human chorionic gonadotropin (hCG). Progesterone governs the secretory transformation of the endometrium prior to implantation and an adequate luteal $\mathrm{P}_{4}$ level is crucial for the establishment and maintenance of early pregnancy (1).

During IVF and fresh embryo transfer, the luteal function is disrupted and the success of the treatment is critically dependent on exogenous luteal phase support (2-5). For decades, this exogenous $\mathrm{P}_{4}$ support has been administered as a standard dose in IVF patients in the firm belief that "one dose fits all." A widely held view has been that the absolute luteal $\mathrm{P}_{4}$ level does not affect the chance of pregnancy, as long as a minimum $\mathrm{P}_{4}$ concentration was reached by means of the administration of exogenous luteal phase support $(6,7)$. However, recent studies have suggested that both very low and very high luteal $\mathrm{P}_{4}$ levels affect the reproductive outcome negatively (8-12). Thus, in a study by Yovich et al., 529 artificial frozen-thawed cycles with single blastocyst transfer were evaluated (8). The authors reported that the optimal pregnancy and live birth rate was achieved when mid-luteal serum $\mathrm{P}_{4}$ was in the range of 70-99 $\mathrm{nmol} / \mathrm{l}$. Below, but also above this range, the clinical pregnancy rate was significantly reduced from 64 to $44 \%$. Following this, several other papers also reported a lower, as well as, higher luteal $\mathrm{P}_{4}$ threshold in artificial frozen-thawed embryo transfer cycles (10-12). In IVF cycles with fresh embryo transfer, the mid-luteal $\mathrm{P}_{4}$ requirement is significantly increased compared to both the natural and the frozen embryo transfer cycle as demonstrated by a work by Humaidan et al. (2). Very recently, our group described the optimal $\mathrm{P}_{4}$ levels during the early and mid-luteal phase of IVF cycles with fresh embryo transfer (9). In a cohort of 602 patients, we observed that reproductive outcomes seemed consistently decreased below, but most distinctly above a defined optimal $\mathrm{P} 4$ range.

Taken together, it seems that both too high and too low luteal $\mathrm{P}_{4}$ concentrations result in reduced pregnancy rates in both fresh and frozen embryo transfer cycles. The findings of a higher and lower $\mathrm{P}_{4}$ threshold seem plausible from a biological point of view: A very high $\mathrm{P}_{4}$ level during the early luteal phase may advance the endometrium leading to asynchrony between embryo development and endometrial receptivity, whereas a very low $\mathrm{P}_{4}$ level fails to support a sufficient secretory transformation in time for implantation. Both scenarios hamper the chance of a live birth.

The CL produces not only $\mathrm{P}_{4}$, but also $17-\mathrm{OH} \mathrm{P}_{4}$ during its lifespan (13). When measuring serum $\mathrm{P}_{4}$ following fresh embryo transfer with the use of exogenous $\mathrm{P}_{4}$ luteal support, the serum $\mathrm{P}_{4}$ value is a combination of the exogenously supplied $\mathrm{P}_{4}$ and the endogenous luteal $\mathrm{P}_{4}$ production. As $17-\mathrm{OH} \mathrm{P}_{4}$ is not supplied as part of the luteal phase support, the serum 17-OH $\mathrm{P}_{4}$ level may reflect more accurately the true CL function compared to the measurement of total $\mathrm{P}_{4}$.

The aim of this study was to explore the possible correlation between mid-luteal serum $17-\mathrm{OH} \mathrm{P}_{4}$ levels and the reproductive outcome in terms of live birth rates following IVF treatment and fresh embryo transfer. Furthermore, if serum 17-OH $\mathrm{P}_{4}$ should serve as an index for CL function, it is evident that the accuracy of a single measurement is important. Therefore, a second aim of the present study was to explore the daytime variations in serum 17- $\mathrm{OH} \mathrm{P}_{4}$ which might affect the clinical interpretation of the measurement.

\section{MATERIALS AND METHODS}

\section{Study Design}

Prospective cohort study.

\section{Patient Population}

The present cohort of patients has previously been described in papers by our group $(9,14)$. Briefly, this study included 614 patients undergoing IVF treatment at four public Danish fertility centers-The Fertility Clinic Skive Region Hospital, The Fertility Clinic Horsens Region Hospital, The Fertility Clinic Herlev Hospital and The Fertility Clinic Odense University Hospital-between May 2014 and June 2017. The patient cohort was unselected, representing normal everyday patients treated in the clinics. All participating patients were under the age of 41 and with a body mass index (BMI) $<35 \mathrm{~kg} / \mathrm{m}^{2}$ as required by Danish national guidelines for public fertility treatment ${ }^{1}$ Treatment choices regarding type of protocol (GnRH agonist or $\mathrm{GnRH}$ antagonist) and trigger type (hCG or GnRH agonist) were made on an individual basis by the attending clinician.

Written and oral information was given to 1,482 patients of whom 609 (41\%) declined to participate mainly due to the extra visit needed at the clinic for mid-luteal blood sampling 7 days after oocyte retrieval (OPU+7). The final study cohort included 614 patients with embryo transfer and relevant study samples taken (Figure 1).

Clinical information regarding primary diagnosis, age, BMI, smoking habits, antral follicle count and basal FSH and LH levels were obtained prior to treatment by the clinical staff. Serum TSH and prolactin levels were within normal range in all patients prior to treatment start. All patients participated once, only. No patients were lost to follow-up.

\section{Ovarian Stimulation}

Patients treated in the long GnRH-agonist protocol were down-regulated using daily SC injections of a GnRH antagonist (Suprefact ${ }^{\circledR}$, Sanofi, Denmark or Gonapepty ${ }^{\circledR}$, Ferring Pharmaceuticals, Denmark) starting in the mid-luteal phase of the preceding cycle and continuing until the day before ovulation induction. Ovarian stimulation was initiated after 12-14 days of down-regulation in case of an endometrial thickness $<4 \mathrm{~mm}$. Final follicle maturation was induced with hCG 5,000-10,000 IU (Pregnyl ${ }^{\circledR}$, MSD, Denmark or Ovitrelle, Merck Biopharma, Denmark) when two or more leading follicles reached a diameter of $\geq 17 \mathrm{~mm}$.

${ }^{1}$ Danish Fertility Society. Guideline 2016: Overweight, Obesity and Fertility Treatment. 


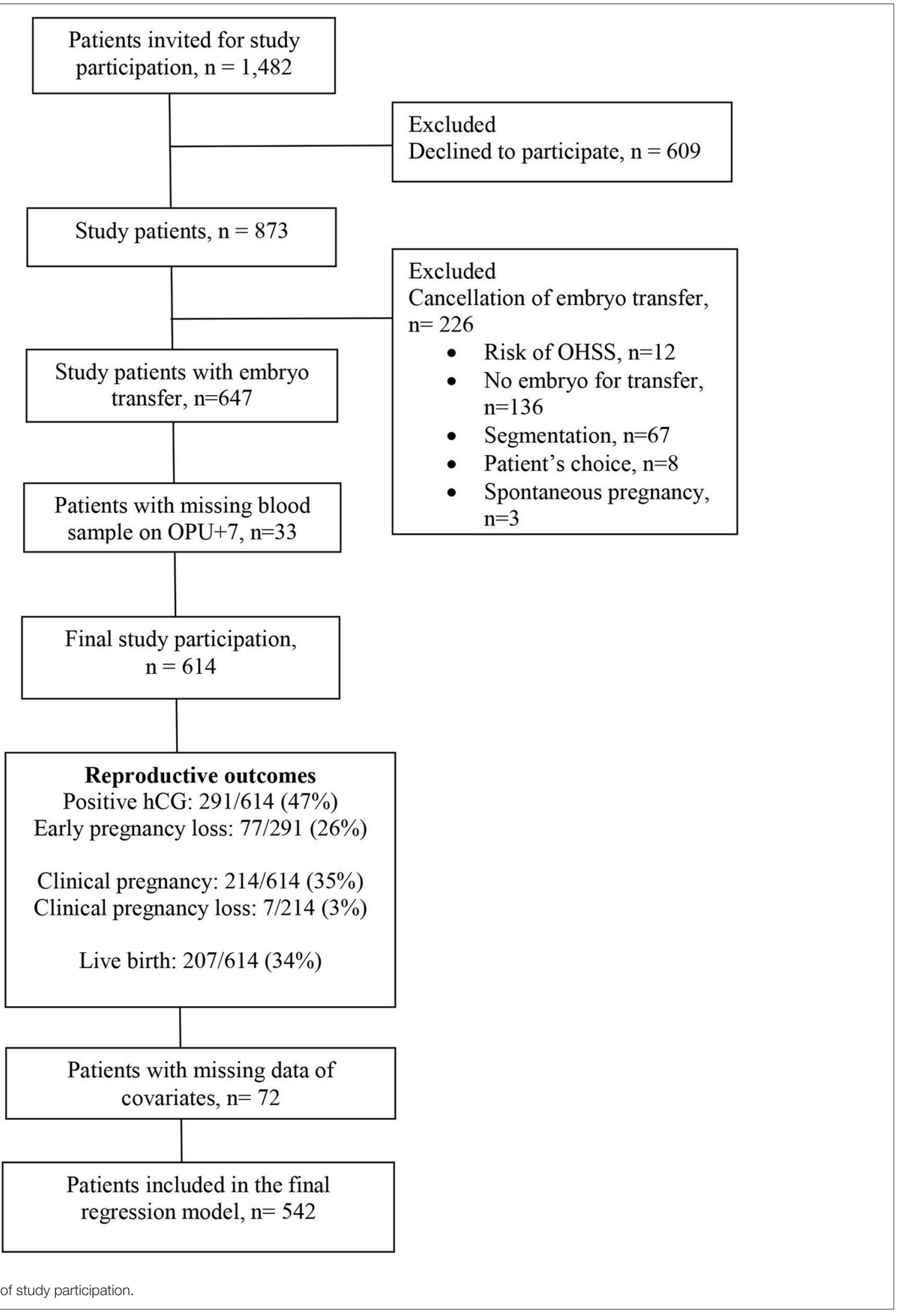


If the GnRH antagonist protocol was used, ovarian stimulation commenced on day 2 or 3 of the cycle after a vaginal ultrasound examination. Daily $\mathrm{GnRH}$ antagonist co-treatment was started from cycle day 6 and continued up until the day of ovulation induction. When at least two follicles reached a size of $\geq 17 \mathrm{~mm}$, final oocyte maturation was induced with SC Buserelin $0.5 \mathrm{mg}$ (Suprefact ${ }^{\circledR}$, Sanofi, Denmark) or hCG 5,000-10,000 IU (Pregnyl $^{\circledR}$, MSD, Denmark or Ovitrelle, Merck Biopharma, Denmark).

Ovarian stimulation was performed with either hMG (Menopur ${ }^{\circledR}$, Ferring Pharmaceuticals, Denmark), r-FSH (Gonal$\mathrm{f}^{\circledR}$, Merck Biopharma, Denmark), or rFSH/LH (Pergoveris, Merck Biopharma, Denmark) alone or in combination with corifollitropin-alfa (Elonva, MSD, Denmark). The initial gonadotropin dosage was determined individually based on previous response to ovarian stimulation, as well as, patient age, body mass index, antral follicle count, and basal levels of follicle stimulating hormone (FSH). Dose adjustments were performed according to ovarian response monitored by transvaginal ultrasound during treatment. Oocyte pick-up (OPU) was carried out $36 \mathrm{~h}$ after trigger administration. In vitro fertilization (IVF) or intracytoplasmic sperm injection (ICSI) was performed according to normal clinical practice. A maximum of two embryos were transferred on either days 2, 3, or 5 following oocyte retrieval.

Trained embryologists on site evaluated the quality of all available embryos. All original embryo scores from the four clinics were subsequently evaluated by two independent leading embryologists and allocated a final score from 1 to 3 (1 being a top-quality embryo, 2 being an intermediate embryo, 3 being a low-quality embryo). In case of incongruence, a second evaluation was performed to reach final agreement.

Briefly, a top-quality embryo on day 2 and 3 was described as having four and eight cells, respectively, equally sized blastomeres, $<10 \%$ fragmentation and no multinucleate cells in accordance with the consensus scoring system for cleavage-stage embryos described by the Alpha Scientist group (15). In case of severe fragmentation $(>25 \%)$, cell-size not stage-specific or evidence of multinucleation the cleavage embryo was classified as low-quality. The remaining cleavage embryos were classified as intermediate.

A top-quality blastocyst had a day 5 score better than $3 \mathrm{BB}$ according to the Gardner standard based on grade of expansion, trophectoderm, and inner-cell mass quality (16). A low-quality blastocyst had a day 5 score $<3 \mathrm{BB}$. The remaining blastocysts $(3 \mathrm{BB}, 4 \mathrm{BB}, 5 \mathrm{BB})$ were described as intermediate.

\section{Luteal Phase Support}

All patients received the same vaginal luteal phase support in a standard regimen using $300 \mathrm{mg}$ micronized $\mathrm{P}_{4}$ daily (Lutinus ${ }^{\circledR}$, Ferring Pharmaceuticals). Intramuscular $\mathrm{P}_{4}$ for luteal support was not used in any of the participating patients. A small fraction of patients $(n=41)$ had one bolus of GnRH agonist (Gonapeptyl $0.1 \mathrm{mg}$ ) on OPU+7 based on an individual clinical assessment. In patients receiving Gonapeptyl ${ }^{\circledR}$, 30/41 were treated in the long $\mathrm{GnRH}$ agonist protocol and 11/41 in the GnRH antagonist protocol. Patients receiving a bolus of $\mathrm{GnRH}$ as luteal phase support were distributed equally across the different $17-\mathrm{OH}$ P4 groups $(p=0.35)$.

In case of a GnRH-agonist trigger, a bolus of hCG on the day of oocyte retrieval (1,500 IU) was given to all patients. Based on the individual ovarian response to stimulation, some patients received an additional bolus of HCG on OPU +5 according to a protocol previously described by Humaidan et al. (17). Vaginal $\mathrm{P}_{4}$ administration continued until the day of pregnancy testing (hCG trigger) or until 7 completed weeks of gestation (GnRHa trigger).

\section{Blood Sampling}

All 614 patients had blood samples performed 7 days after oocyte pick-up (OPU+7) for hormone measurements and 14 days after oocyte pick-up $(\mathrm{OPU}+14)$ for pregnancy testing.

On OPU +7 , seven patients agreed to have a series of blood samples performed during daytime to assess the possible variation in serum $17-\mathrm{OH} \mathrm{P}_{4}$ levels over time. These seven women were admitted to the fertility unit at Skive Region Hospital early in the morning and stayed at the clinic for the subsequent $12 \mathrm{~h}$. The starting time for blood sampling was between 6 and 8 a.m. for all patients. Participants were allowed normal daily life activities during the study period. An intravenous cannula was inserted into a vein in the antecubital fossa and blood samples $(4 \mathrm{ml})$ were drawn every $60 \mathrm{~min}$ for $12 \mathrm{~h}$ $(n=7)$ and for two of these hours every $15 \mathrm{~min}$ ( $n=6$ because of difficult venous access in one patient).

After coagulation at room temperature, all blood samples were centrifuged, and serum was isolated and divided into three separate aliquots to allow for analyses at different laboratories. Individual serum samples were stored at $-80^{\circ} \mathrm{C}$ until analysis. Blood samples from the total cohort $(n=614)$ were analyzed for 17-OH $\mathrm{P}_{4}$ and $\mathrm{P}_{4}$, whereas the series of blood samples in the small cohort $(n=7)$ were analyzed for $17-\mathrm{OH} \mathrm{P}_{4}$ and $\mathrm{LH}$.

\section{Hormone Assays}

Serum 17-OH progesterone concentrations were measured using liquid chromatography-tandem mass spectrometry (LC-MS/MS) at the Department of Biochemistry, Aarhus University Hospital, Denmark. The assay allowed quantification of $17-\mathrm{OH} \mathrm{P}_{4}$ in the range $0.37-78.7 \mathrm{nmol} / 1$ without dilution of samples. The accuracy was $\pm 0.32 \mathrm{nmol} / \mathrm{l}$ at $17-\mathrm{OH} \mathrm{P}_{4}$ concentrations of $1.3, \pm 0.90$ $\mathrm{nmol} / \mathrm{l}$ at $17-\mathrm{OH} \mathrm{P}_{4}$ concentrations of 6.4 and $\pm 6.6 \mathrm{nmol} / \mathrm{l}$ at 17-OH $\mathrm{P}_{4}$ concentrations of $47.0 \mathrm{nmol} / 1$.

Serum $\mathrm{P}_{4}$ and serum $\beta$-hCG concentrations were measured at the Department of Biochemistry, Odense University Hospital, Denmark using commercial automated electro chemiluminescent immunoassays (Immulite ${ }^{\circledR}$ 2000XPi, Siemens Healthcare, Denmark and Architect ${ }^{\circledR}$ i2000SR, Abbott Diagnostics, USA) routinely used for analysis. Serum LH concentrations were measured at the Department of Biochemistry, Viborg Region Hospital, Denmark, using commercial automated electro chemiluminescent immunoassays (Cobas ${ }^{\circledR}$ Modular analytics E170, Roche Diagnostics, Switzerland). The detection limit for $\mathrm{P}_{4}$ was $0.6 \mathrm{nmol} / \mathrm{l}$, and the in-house inter- and intra-assay coefficients of variation 
were 4.4 and $1.6 \%$, respectively. The detection limit for hCG was $1.2 \mathrm{IU} / \mathrm{l}$ and the in-house inter- and intra-assay coefficients of variation were 3.4 and $1.7 \%$, respectively. The detection limit for LH was $0.1 \mathrm{IU} / \mathrm{l}$ and the in-house inter- and intra-assay coefficients of variation were 3.8 and $1.8 \%$, respectively.

\section{Exposure}

Patients were divided into four $17-\mathrm{OH} \mathrm{P}_{4}$ groups based on raw data of pregnancy outcomes: $17-\mathrm{OH} \mathrm{P}_{4}<6,6-14,14.1-30$, and $>30 \mathrm{nmol} / \mathrm{l}$ (Supplementary Figure 1). The lower threshold of $6 \mathrm{nmol} / \mathrm{l}$ corresponds to the mid-luteal $17-\mathrm{OH} \mathrm{P}_{4}$ level of the natural cycle (18).

In sensitivity analyses, estimates were also calculated based on 25/50/75 percentiles, as well as, 10/50/90 percentiles (Supplementary Figure 1).

\section{Outcome Variables}

Serum $\beta$-hCG concentration was determined on OPU+14 and was considered positive if $\beta$-hCG $>10 \mathrm{IU} / \mathrm{l}$. In case of a $\beta$-hCG level between 10 and $45 \mathrm{IU} / \mathrm{l}$, a control $\beta$-hCG was performed after $48 \mathrm{~h}$. Clinical pregnancy was defined as the presence of a live fetus within an intra-uterine gestational sac at ultrasound examination in gestational weeks 7-8. Early pregnancy loss was defined as (1) patients with an insufficient $\beta$-hCG value at the day of pregnancy testing (10-45 IU/l) and decreasing $\beta$-hCG values toward null in subsequent hCG-controls (2) patients with a positive hCG but no intra- or extrauterine sac visualized on transvaginal ultrasound in gestational weeks $7-8$, and (3) patients with a fetus without visible heartbeat at UL in gestational weeks 7-8. Clinical pregnancy loss was defined as the loss of a viable intrauterine pregnancy up to and including gestational weeks $20+0$. Live birth was defined as the delivery of a live infant after gestational weeks $20+0$. For description of gestational age, clinical gestational dating was applied using the day of oocyte retrieval as gestational weeks $2+0$.

\section{Confounding Factors}

The confounding factors included in the regression model were chosen a priori based on a Directed Acyclic Graph (DAG) (Supplementary Figure 2). DAGs are visual representations of causal paths between exposure and outcome $(19,20)$. Drawing and analysis of a DAG can help to identify confounding factors that obscure the real effect of the exposure on the outcome. Based on a structured analysis of the DAG, it is possible to identify a minimum, however sufficient set of covariates to adjust for in the statistical analysis, which will cover all confounding elements. The web application DAGitty was used to draw and analyze the DAGs used in this paper.

\section{Statistical Methods}

Data are presented as mean and standard deviation for continuous parametric variables, percentages for categorical variables and median and range for continuous, non-parametric variables. Differences in categorical variables between 17$\mathrm{OH} \mathrm{P}_{4}$ groups were assessed with Fishers exact test or Pearson's chi-square test when appropriate. Differences in continuous parametric data between the four $17-\mathrm{OH} \mathrm{P}_{4^{-}}$ groups were assessed using one-way analysis of variance (ANOVA) followed by a post-hoc pairwise comparison in case of a statistical difference between groups. Normality was checked by QQ-plots, and the assumption of variance homogeneity was tested by Bartlett's test. Kruskal-Wallis test was used in case of non-parametric continuous data.

A multiple logistic regression model was used to assess the association between mid-luteal 17-OH $\mathrm{P}_{4}$ levels and the hCG test result (positive/negative), clinical pregnancy (yes/no) and early pregnancy loss (yes/no), and live birth (yes/no). The model included the independent variables maternal age (continuous, ln-transformed), maternal BMI (continuous, lntransformed), smoking (yes/no), final follicle count on the day of trigger (continuous, In-transformed), late follicular phase $\mathrm{P}_{4}$ level [dichotomous $(>4.77$ or $\leq 4.77 \mathrm{nmol} / \mathrm{l})$ ] and day of transfer [dichotomous (cleavage-stage or blastocyst)] for estimates of positive hCG rate, clinical pregnancy rate, and live birth rate. For estimates of early pregnancy loss adjustment was made for maternal age (continuous, lntransformed), maternal BMI (continuous, ln-transformed), smoking (dichotomous), final follicle count (continuous, lntransformed), day of transfer [dichotomous (cleavage-stage or blastocyst)] and peak estradiol level on the day of trigger (continuous, ln-transformed). The cut-off for late follicular phase progesterone $(>4.77 \mathrm{ng} / \mathrm{ml}$ equivalent to $>1.5 \mathrm{ng} / \mathrm{ml})$ was chosen based on the results of earlier studies (21, 22).

In case of missing data of covariates, patients were omitted from the final regression analysis $(n=72)$. A $p<0.05$ was considered statistically significant. All statistical analyses were performed using STATA version 13.

\section{Ethics}

The study was conducted according to the declaration of Helsinki for Medical Research and approved by the local Ethics Committee of Central Denmark Region (M-2012-42312). All patients gave their written and oral consent prior to study participation. ClinicalTrial.gov registration number NCT02129998.

\section{RESULTS}

\section{Demographic Data}

The population consisted of 614 women undergoing IVF/ICSI treatment followed by fresh embryo transfer on either days 2, 3, or 5. Demographic data are shown in Table 1. Overall, patients had a mean age of $32.5 \pm 4.6$ years and a mean BMI of $25.1 \pm 4.2 \mathrm{~kg} / \mathrm{m}^{2}$. Maternal age, basal $\mathrm{LH}$, basal FSH and smoking did not differ between $17-\mathrm{OH} \mathrm{P}_{4}$ groups. Paternal age and BMI showed no significant differences between 17-OH $\mathrm{P}_{4}$ groups (data not shown). Maternal BMI was significantly higher in the low $17-\mathrm{OH} \mathrm{P}_{4}$ group $\left(17-\mathrm{OH} \mathrm{P}_{4}\right.$ $<6 \mathrm{nmol} / \mathrm{l}$ ) compared pairwise to any of the other $17-\mathrm{OH}$ $\mathrm{P}_{4}$ groups (all pairwise $p<0.001$ ). Antral follicle count and the distribution of women with PCOS differed significantly 
TABLE 1 | Baseline characteristics of study patients in different 17-OH $\mathrm{P}_{4}$ groups.

\begin{tabular}{|c|c|c|c|c|c|c|c|}
\hline 17-OH P 4 (nmol/l) & $N$ & All & $<6$ & $6-14$ & $14.1-30$ & $>30$ & $p$ \\
\hline Number of patients, $n$ & 614 & & 183 & 134 & 132 & 165 & \\
\hline Maternal age, years & 614 & $32.5 \pm 4.6$ & $33.0 \pm 4.9$ & $32.2 \pm 4.6$ & $32.7 \pm 4.5$ & $32.0 \pm 4.2$ & 0.195 \\
\hline Maternal BMI, kg/m² & 614 & $25.1 \pm 4.2$ & $26.3 \pm 4.0$ & $24.2 \pm 4.1$ & $24.7 \pm 4.4$ & $24.5 \pm 4.1$ & $<0.001$ \\
\hline Maternal smoking,\% & 614 & 8 & 10 & 8 & 4 & 9 & 0.197 \\
\hline Basal FSH, IU & $573^{\star}$ & $\begin{array}{c}6.2 \\
(0.1-22.0)\end{array}$ & $\begin{array}{c}6.1 \\
(0.3-22.0)\end{array}$ & $\begin{array}{c}6.7 \\
(0.1-17.5)\end{array}$ & $\begin{array}{c}6.4 \\
(0.3-15.5)\end{array}$ & $\begin{array}{c}6.0 \\
(1.1-14.7)\end{array}$ & 0.544 \\
\hline Basal LH, IU & $554^{\star \star}$ & $\begin{array}{c}5.4 \\
(0.1-40.0)\end{array}$ & $\begin{array}{c}5.2 \\
(0.2-40.0)\end{array}$ & $\begin{array}{c}5.2 \\
(0.1-19.0)\end{array}$ & $\begin{array}{c}5.4 \\
(0.1-17.0)\end{array}$ & $\begin{array}{c}5.6 \\
(0.4-24.0)\end{array}$ & 0.792 \\
\hline Antral follicle count, $n$ & 614 & $\begin{array}{c}13 \\
(2-50)\end{array}$ & $\begin{array}{c}12 \\
(2-33)\end{array}$ & $\begin{array}{c}14 \\
(3-40)\end{array}$ & $\begin{array}{c}12 \\
(2-38)\end{array}$ & $\begin{array}{c}13 \\
(4-50)\end{array}$ & 0.004 \\
\hline Primary diagnosis, & 614 & & & & & & \\
\hline Unexplained, \% & & 25 & 21 & 22 & 30 & 29 & $0.200^{\star \star \star}$ \\
\hline Tubal, \% & & 9 & 7 & 8 & 11 & 11 & 0.426 \\
\hline PCO/PCOS, \% & & 11 & 11 & 13 & 5 & 14 & 0.028 \\
\hline Endometriosis, \% & & 6.5 & 7 & 7 & 7 & 5 & 0.781 \\
\hline Male, \% & & 38 & 39 & 45 & 37 & 30 & 0.074 \\
\hline Single/female partner, \% & & 10 & 14 & 5 & 9 & 10 & 0.095 \\
\hline Other, \% & & 1 & 1 & 0 & 1 & 1 & 0.895 \\
\hline
\end{tabular}

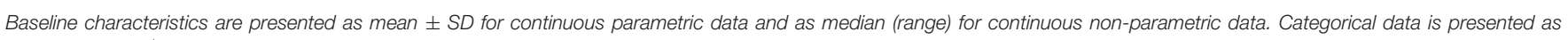

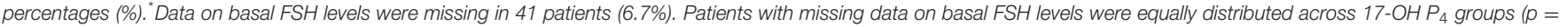

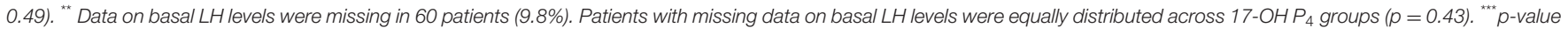

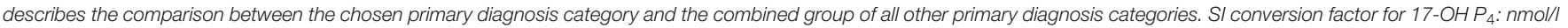
$=3.03^{*} \mathrm{ng} / \mathrm{ml}$.

between groups, albeit with no apparent clinically relevant differences.

\section{Cycle Characteristics}

A total of $63 \%$ of patients were treated in a $\mathrm{GnRH}$ antagonist protocol, whereas a long $\mathrm{GnRH}$ agonist protocol was used in $37 \%$ of patients. Final oocyte maturation was achieved using hCG trigger in $58 \%$ of patients and using $\mathrm{GnRH}$ agonist trigger in $42 \%$ of patients. In total, $64 \%$ of patients had a top-quality embryo for transfer (Table 2).

The low 17-OH $\mathrm{P}_{4}$ group ( $\left.<6 \mathrm{nmol} / \mathrm{l}\right)$ and the high $17-\mathrm{OH} \mathrm{P}_{4}$ group $(>30 \mathrm{nmol} / \mathrm{l})$ both had a significantly higher final follicle count $(p=0.01)$ and a significantly higher number of oocytes retrieved $(p=0.01)$ compared to the two remaining $17-\mathrm{OH} \mathrm{P}_{4}$ groups. Furthermore, total FSH dose, duration of stimulation and the luteal phase support regime differed between groups (Table 2).

Single embryo transfer was applied in $81 \%$ and double embryo transfer in $19 \%$ of patients. There was no significant difference between the number of embryos transferred across $17-\mathrm{OH}$ $\mathrm{P}_{4}$ groups $(p=0.66)$ A cleavage-stage embryo transfer was performed on day 2 or 3 in $72 \%$ of patients, whereas $28 \%$ had a blastocyst transfer on day 5 . The study blastocyst transfer rate is in line with the present blastocyst transfer rate for all public IVF clinics in Denmark ${ }^{2}$. The percentages of patients with blastocyst transfer were comparable across the four $17-\mathrm{OH} \mathrm{P}_{4}$ groups $(p=$ 0.42 ). Likewise, the mean embryo score was similar in different $17-\mathrm{OH} \mathrm{P}_{4}$ groups for both SET $(p=0.09)$ and DET transfers $(p$ $=0.92$ ).

\footnotetext{
${ }^{2}$ Danish Fertility Society. Annual Report 2017.
}

\section{Mid-Luteal 17-OH $\mathbf{P}_{\mathbf{4}}$ Levels}

The median 17- $\mathrm{OH} \mathrm{P}_{4}$ concentration measured on OPU+7 was $13.2 \mathrm{nmol} / \mathrm{l}$, range $0.5-129.0 \mathrm{nmol} / \mathrm{l}$. The median $\mathrm{P}_{4}$ concentration was $113 \mathrm{nmol} / \mathrm{l}$, range $16.3-1685.0 \mathrm{nmol} / \mathrm{l}$. There was a significant, positive association between $\mathrm{P}_{4}$ levels and 17$\mathrm{OH} \mathrm{P}_{4}$ levels, $p<0.001$ (Figure 2A). Thus, an increase of 100 $\mathrm{nmol} / \mathrm{l}$ in serum $\mathrm{P}_{4}$ levels corresponded to an increase in serum 17-OH $\mathrm{P}_{4}$ levels of $9.5 \mathrm{nmol} / 1,95 \% \mathrm{CI}$ [9.0;9.9]. This ratio between serum $17-\mathrm{OH} \mathrm{P}_{4}$ and serum $\mathrm{P}_{4}$ of $\sim 10 \%$ was constant with increasing levels of $\mathrm{P}_{4}, p=0.67$ (Figure 2B). However, a large inter-individual difference in the secretion pattern of $\mathrm{P}_{4}$ and 17$\mathrm{OH} \mathrm{P}_{4}$ was noticed. To illustrate this, the 19 patients in the cohort with serum $\mathrm{P}_{4}$ values between $400-450 \mathrm{nmol} / \mathrm{l}$ are marked in red in Figure 2A. Despite comparable levels of $\mathrm{P}_{4}$ in these patients, the range of $17-\mathrm{OH} \mathrm{P} \mathrm{P}_{4}$ varied from levels as low as $4.4 \mathrm{nmol} / \mathrm{l}$ up to $114 \mathrm{nmol} / \mathrm{l}$.

Patients were equally distributed in the four chosen 17$\mathrm{OH} \mathrm{P}_{4}$ groups. Out of the total cohort of 614 patients, 30\% $(n=183)$ had $17-\mathrm{OH} \mathrm{P}_{4}$ levels $<6 \mathrm{nmol} / \mathrm{l}, 22 \%(n=134)$ had 17-OH $\mathrm{P}_{4}$ levels between 6 and $14 \mathrm{nmol} / \mathrm{l}, 21 \%(n=$ 132) had 17-OH $\mathrm{P}_{4}$ levels between 14.1 and $30 \mathrm{nmol} / \mathrm{l}$ and finally, 27\% $(n=165)$ had $17-\mathrm{OH} \mathrm{P}_{4}$ levels $>30 \mathrm{nmol} / \mathrm{l}$. The 72 patients (12\%) who were omitted from the final regression analysis due to missing values of covariates, were equally distributed across the four $17-\mathrm{OH} \mathrm{P}_{4}$ groups $(p=$ $0.94)$.

\section{Reproductive Outcomes}

The overall rate for positive hCG per transfer was $47 \%$ (291/614), the clinical pregnancy rate per transfer was 35\% $(214 / 614)$ and the overall live birth rate per transfer was 
TABLE 2 | Descriptive data of controlled ovarian stimulation, oocytes, embryo transfer, and luteal phase support.

\begin{tabular}{|c|c|c|c|c|c|c|}
\hline 17-OH $\mathrm{P}_{4}, \mathrm{nmol} / \mathrm{I}$ & All & $<6$ & $6-14$ & 14.1-30 & $>30$ & $p$ \\
\hline Number of patients $(n)$ & 614 & 183 & 134 & 132 & 165 & \\
\hline $\begin{array}{l}\text { Protocol } \\
\text { Antagonist (\%) } \\
\text { Long GnRH agonist (\%) }\end{array}$ & $\begin{array}{l}63 \\
37\end{array}$ & $\begin{array}{l}51 \\
49\end{array}$ & $\begin{array}{l}58 \\
42\end{array}$ & $\begin{array}{l}61 \\
39\end{array}$ & $\begin{array}{l}81 \\
19\end{array}$ & $<0.001$ \\
\hline Total FSH dose (IU) & $\begin{array}{c}2,250 \\
(500-7,350)\end{array}$ & $\begin{array}{c}2,450 \\
(900-6,750)\end{array}$ & $\begin{array}{c}2,063 \\
(788-7350)\end{array}$ & $\begin{array}{c}2,475 \\
(900-5025)\end{array}$ & $\begin{array}{c}1,950 \\
(500-7,350)\end{array}$ & $<0.001$ \\
\hline Stim duration (days) & $10.4 \pm 2.0$ & $10.4 \pm 1.9$ & $10.6 \pm 2.1$ & $10.6 \pm 2.1$ & $9.9 \pm 1.9$ & 0.006 \\
\hline $\begin{array}{l}\text { Final follicle count }>12 \mathrm{~mm} \text { on } \\
\text { trigger day }\end{array}$ & $\begin{array}{c}10 \\
(1-29)\end{array}$ & $\begin{array}{c}10 \\
(1-29)\end{array}$ & $\begin{array}{c}9 \\
(1-22)\end{array}$ & $\begin{array}{c}9 \\
(3-20)\end{array}$ & $\begin{array}{c}10 \\
(1-26)\end{array}$ & 0.005 \\
\hline \multicolumn{7}{|l|}{$\begin{array}{l}\text { Mode of triggering for final oocyte } \\
\text { maturation }\end{array}$} \\
\hline hCG (\%) & 58 & 67 & 72 & 61 & 35 & $<0.001$ \\
\hline GnRH agonist (\%) & 42 & 33 & 28 & 39 & 65 & \\
\hline Number of oocytes retrieved (n) & $\begin{array}{c}8 \\
(1-28)\end{array}$ & $\begin{array}{c}9 \\
(1-23)\end{array}$ & $\begin{array}{c}8 \\
(1-26)\end{array}$ & $\begin{array}{c}8 \\
(1-24)\end{array}$ & $\begin{array}{c}9 \\
(2-28)\end{array}$ & 0.014 \\
\hline Number of fertilized oocytes (n) & $\begin{array}{c}8 \\
(1-27)\end{array}$ & $\begin{array}{c}8 \\
(1-23)\end{array}$ & $\begin{array}{c}8 \\
(1-23)\end{array}$ & $\begin{array}{c}7 \\
(1-24)\end{array}$ & $\begin{array}{c}8 \\
(2-27)\end{array}$ & 0.033 \\
\hline $\begin{array}{l}\text { Single embryo transfer (\%) } \\
\text { Double embryo transfer (\%) }\end{array}$ & $\begin{array}{l}81 \\
19\end{array}$ & $\begin{array}{l}79 \\
21\end{array}$ & $\begin{array}{l}79 \\
21\end{array}$ & $\begin{array}{l}83 \\
17\end{array}$ & $\begin{array}{l}83 \\
17\end{array}$ & 0.661 \\
\hline $\begin{array}{l}\text { At least one top quality embryo for } \\
\text { transfer (\%) }\end{array}$ & 64 & 66 & 59 & 70 & 64 & 0.160 \\
\hline $\begin{array}{l}\text { Mean embryo score, } \\
\text { SET } \\
\text { DET }\end{array}$ & $\begin{array}{l}1.4 \pm 0.6 \\
1.7 \pm 0.6\end{array}$ & $\begin{array}{l}1.4 \pm 0.6 \\
1.7 \pm 0.6\end{array}$ & $\begin{array}{l}1.5 \pm 0.7 \\
1.7 \pm 0.7\end{array}$ & $\begin{array}{l}1.3 \pm 0.5 \\
1.6 \pm 0.7\end{array}$ & $\begin{array}{l}1.5 \pm 0.7 \\
1.6 \pm 0.6\end{array}$ & $\begin{array}{l}0.090 \\
0.915\end{array}$ \\
\hline $\begin{array}{l}\text { Day of transfer, } \\
\text { Cleavage-stage embryo transfer (\%) } \\
\text { Blastocyst transfer (\%) }\end{array}$ & $\begin{array}{l}72 \\
28\end{array}$ & $\begin{array}{l}72 \\
28\end{array}$ & $\begin{array}{l}72 \\
28\end{array}$ & $\begin{array}{l}77 \\
23\end{array}$ & $\begin{array}{l}68 \\
32\end{array}$ & 0.418 \\
\hline Luteal phase support & & & & & & \\
\hline $\begin{array}{l}\text { Vaginal progesterone only (\%) } \\
\quad+1 \text { bolus of hCG (\%) } \\
\quad+2 \text { boluses of hCG (\%) } \\
\text { Vaginal P + Gonapeptyl (\%) }\end{array}$ & $\begin{array}{c}52 \\
17 \\
25 \\
6\end{array}$ & $\begin{array}{c}61 \\
28 \\
4 \\
7\end{array}$ & $\begin{array}{c}66 \\
19 \\
8 \\
7\end{array}$ & $\begin{array}{c}53 \\
9 \\
30 \\
8\end{array}$ & $\begin{array}{c}31 \\
9 \\
56 \\
4\end{array}$ & $\begin{array}{c}<0.001^{\star} \\
<0.001 \\
<0.001 \\
0.353\end{array}$ \\
\hline
\end{tabular}

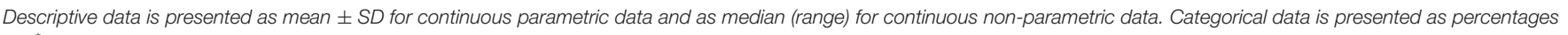

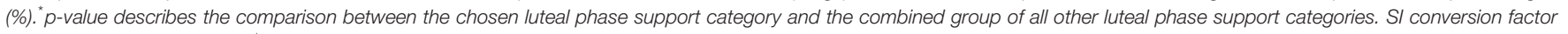
for $17-\mathrm{OHP}$ : $\mathrm{nmol} / \mathrm{l}=3.03{ }^{*} \mathrm{ng} / \mathrm{ml}$.

$34 \%$ (207/614). The early pregnancy loss rate was $26 \%$ (77/291), and the clinical pregnancy loss was 3\% (7/214). The minimum and maximum levels of $17-\mathrm{OH} \mathrm{P}_{4}$ in patients with a live birth were $0.65 \mathrm{nmol} / \mathrm{l}$ and $114 \mathrm{nmol} / \mathrm{l}$, respectively.

When evaluating the association between mid-luteal $17-\mathrm{OH}$ $\mathrm{P}_{4}$ and reproductive outcomes, the optimal serum level of 17$\mathrm{OH} \mathrm{P}_{4}$ was between 6 and $14 \mathrm{nmol} / \mathrm{l}$. Below but also above this level, the OR for positive hCG, clinical pregnancy and live birth showed a non-linear pattern indicating a negative impact on the reproductive outcomes (Figure 3). Thus, OR for live birth in the low $17-\mathrm{OH} \mathrm{P}_{4}$ group was $0.61,95 \% \mathrm{CI}$ $[0.36 ; 1.01], p=0.06$. Likewise, above the optimal 17-OH $\mathrm{P}_{4}$ range the OR for live birth was significantly decreased: OR $0.59,95 \% \mathrm{CI}[0.35 ; 0.98], p=0.04$. As seen from Figure 3, the association between $17-\mathrm{OH} \mathrm{P}_{4}$ and reproductive outcomes displays a non-linear pattern and the negative impact of a high mid-luteal 17-OH $\mathrm{P}_{4}$ level seems to be just as strong as the negative impact of low $17-\mathrm{OH} \mathrm{P}_{4}$ in the peri-implantation period.
In sensitivity analyses, adding trigger type, or protocol type to the statistical model did not change estimates significantly. Furthermore, when using 25/50/75 percentiles or 10/50/90 percentiles to define four $17-\mathrm{OH} \mathrm{P}_{4}$ groups, the same non-linear pattern for reproductive outcomes was found as seen with the a priori chosen $17-\mathrm{OH} \mathrm{P}_{4}$ groups presented above, however, with smaller differences between groups (Supplementary Figure 1).

For a reference person (30 years old, BMI $25 \mathrm{~kg} / \mathrm{m}^{2}, 8$ follicles on the day of trigger, late follicular phase $\mathrm{P}_{4} \leq 4.77 \mathrm{nmol} / \mathrm{l}$, nonsmoker) the chance of a live birth following blastocyst transfer was $53 \%, 95 \% \mathrm{CI}[42 ; 64 \%]$ if mid-luteal $17-\mathrm{OH} \mathrm{P}_{4}$ was within the optimal range (6-14 nmol/l). With mid-luteal $17-\mathrm{OH} \mathrm{P}_{4}$ levels above the optimal range, the chance of a live birth decreased significantly to $41 \%, 95 \%$ CI [31;52\%], thus an absolute risk difference of -12 percentage points, 95\% CI [-22\%;-0.01\%], $p=0.04$. With mid-luteal $17-\mathrm{OH} \mathrm{P}_{4}$ levels below the optimal level, the chance of a live birth was $43 \%, 95 \%$ CI [33;53\%], thus an absolute risk difference of -10 percentage points, $95 \% \mathrm{CI}$ $[-21 ; 0.1 \%], p=0.07$. 

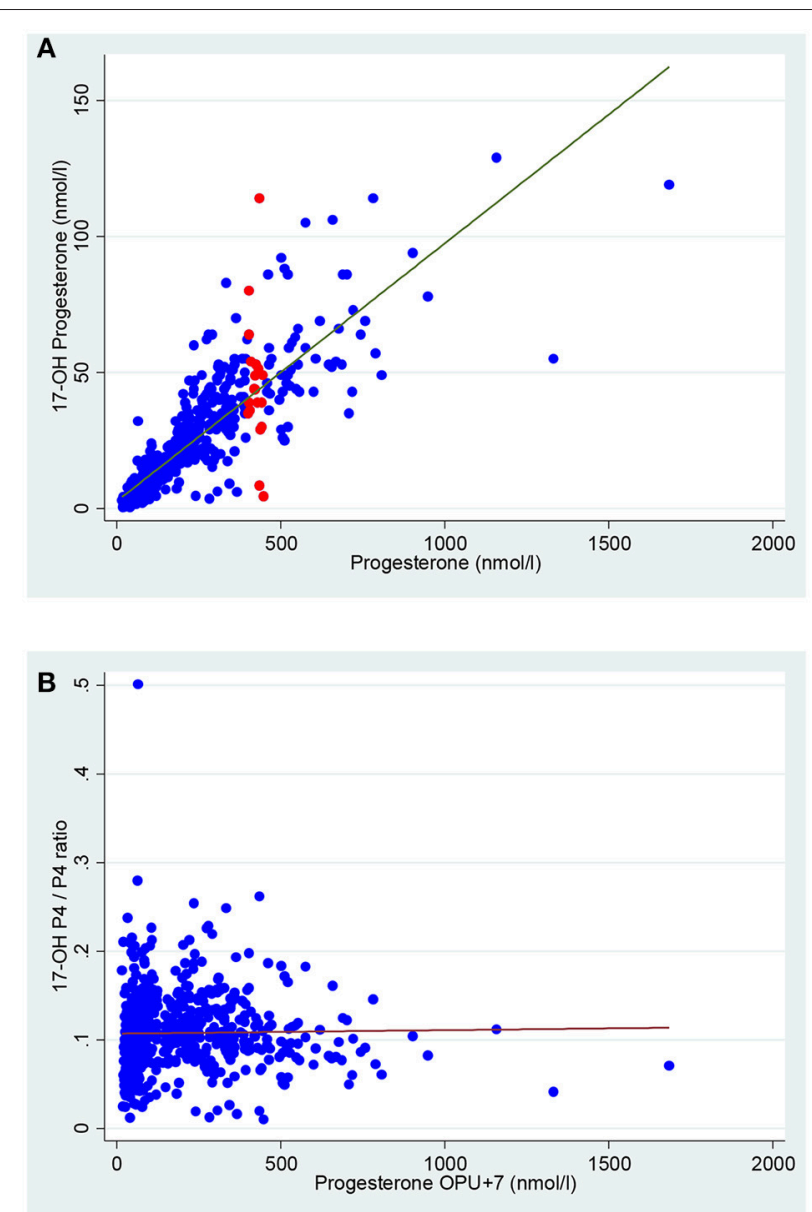

FIGURE 2 | Correlation between mid-luteal serum 17-OH P4 and serum P4 in 614 women undergoing IVF treatment. (A) A significant positive correlation was found between serum $\mathrm{P}_{4}$ and serum 17- $\mathrm{OH} \mathrm{P}_{4}, p<0.001$. Red dots depict the 19 patients in the cohort with $\mathrm{P}_{4} 400-450 \mathrm{nmol} / \mathrm{l}$. (B) The ratio between serum 17- $\mathrm{OH} \mathrm{P}_{4}$ and serum $\mathrm{P}_{4}$ was constant at $\sim 10 \%$ throughout the $\mathrm{P}_{4}$ range, $p=0.67$. The linear regression line is marked in red.
No significant correlation between mid-luteal 17-OH $\mathrm{P}_{4}$ levels and early pregnancy loss was found (Table 3 ).

\section{Daytime Variations in Serum 17-OH $\mathrm{P}_{4}$ Levels}

Figure 4 shows the individual daytime variations in mid-luteal serum 17-OH $\mathrm{P}_{4}$ concentration in seven women undergoing IVF treatment. Three of these women (\#4,\#5, and \#6) had very low endogenous $17-\mathrm{OH} \mathrm{P}_{4}$ production with median concentrations during daytime between 1.9 and $3.8 \mathrm{nmol} / \mathrm{l}$ compared to 13.2 $\mathrm{nmol} / \mathrm{l}$ for the total study cohort. It is seen from Figure 4 that in patients with diminished luteal phase $17-\mathrm{OH}_{4}$ production $(<6$ $\mathrm{nmol} / \mathrm{l})$, serum concentrations of $17-\mathrm{OH} \mathrm{P} \mathrm{P}_{4}$ displayed a constant pattern though out daytime without any significant fluctuations. In contrast, in patients with $17-\mathrm{OH} \mathrm{P}_{4}$ levels above $6 \mathrm{nmol} / \mathrm{l}$, sudden fluctuations in 17-OH $\mathrm{P}_{4}$ occurred randomly in different patients without any obvious common pattern. In patient \#1, 17OH $\mathrm{P}_{4}$ increased $12.8 \mathrm{nmol} / \mathrm{l}$ in just $15 \mathrm{~min}$ (12.45-13.00 p.m.). This rise in concentration corresponds to an increase of $53 \%$ compared to the median level for the day, and this rise occurred even though LH levels were below the detection limit throughout the study period (LH data not shown).

\section{DISCUSSION}

This prospective study, including 614 women undergoing IVF and fresh embryo transfer, aimed at investigating whether the mid-luteal serum 17-OH $\mathrm{P}_{4}$ concentration-used as an index of corpus luteum (CL) function-affects the reproductive outcome. The results suggest that positive hCG rates, clinical pregnancy rates, and live birth rates are reduced outside the defined optimal range for $17-\mathrm{OH} \mathrm{P}_{4}(6-14 \mathrm{nmol} / \mathrm{l})$. Furthermore, for the first time in IVF patients, we monitored the variation in mid-luteal serum 17-OH $\mathrm{P}_{4}$ levels showing that patients with diminished CL function displayed a constant hormone pattern without any significant daytime fluctuations in serum $17-\mathrm{OH} \mathrm{P}_{4}$ concentrations.

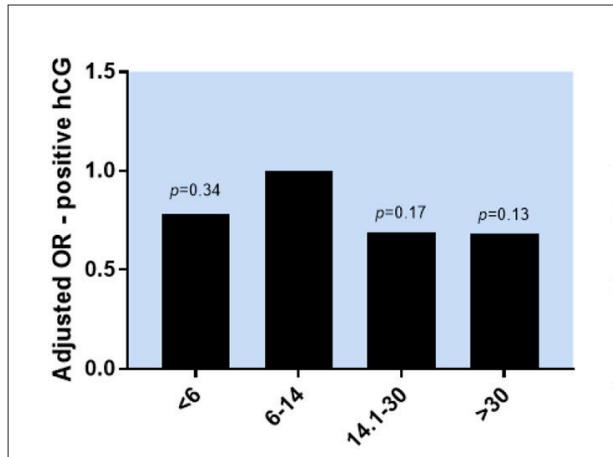

Mid-luteal 17-OH $\mathrm{P}_{4}(\mathrm{nmol})$

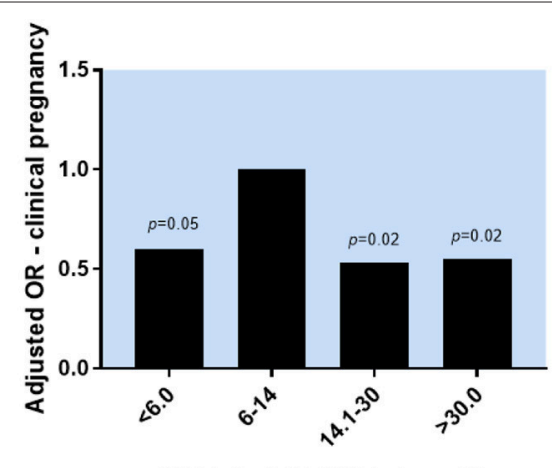

Mid-luteal 17-OH $\mathrm{P}_{4}$ (nmol/l)

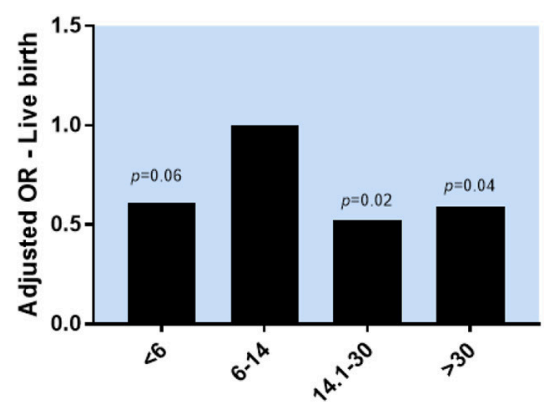

Mid-luteal 17-OH $\mathrm{P}_{4}$ (nmol)

FIGURE 3 | The association between mid-luteal serum 17-OH P 4 levels and reproductive outcomes. OR for positive hCG, clinical pregnancy and live birth in different 17-OH P4 groups adjusted for maternal age, maternal BMI, day of embryo transfer, late follicular P4 levels, smoking and final number of follicles. P-values refer to the pairwise comparison between each 17-OH P4 category and the reference group (6-14 nmol/I). 


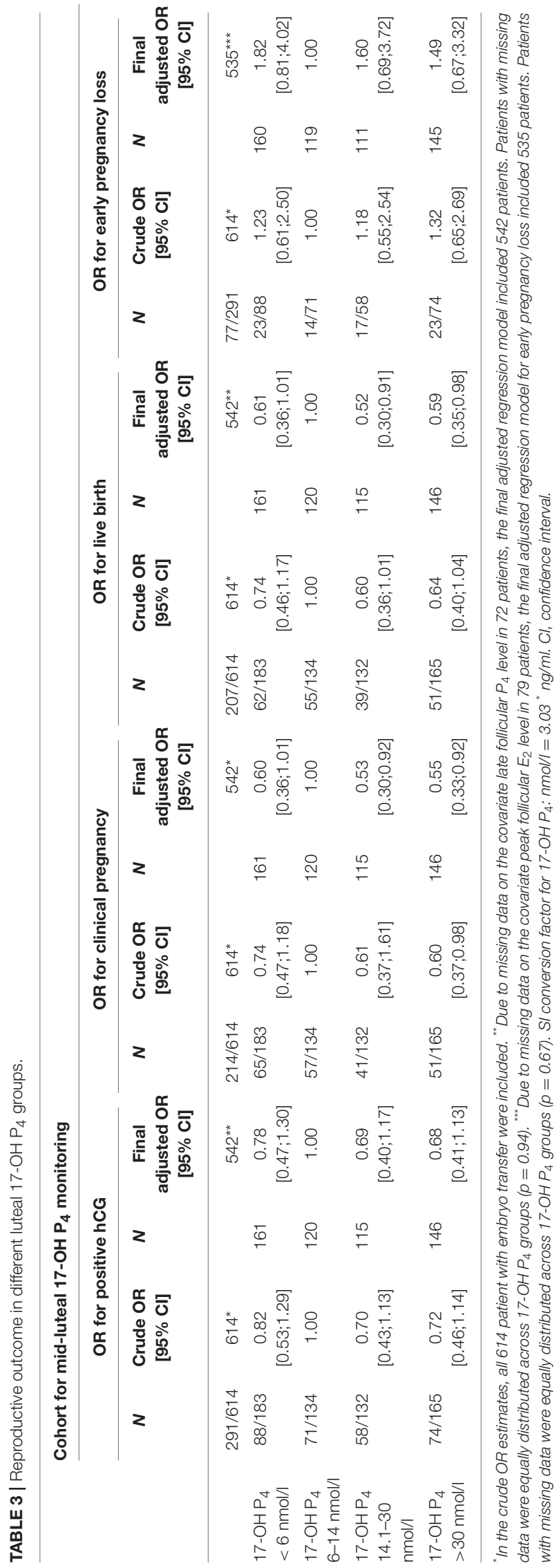

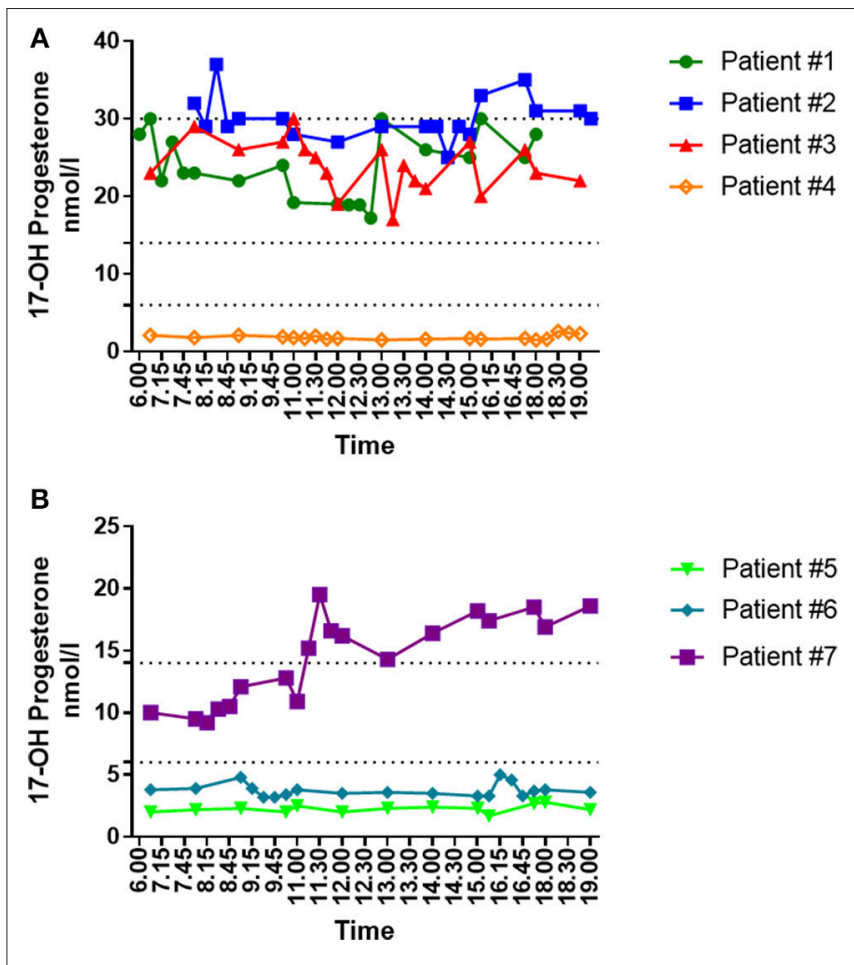

FIGURE 4 | Individual daytime variation in mid-luteal serum 17-OH $\mathrm{P}_{4}$ levels in women undergoing IVF treatment and fresh embryo transfer. (A) Daytime variations in mid-luteal serum $17-\mathrm{OH} \mathrm{P}_{4}$ in four women treated in the long $\mathrm{GnRH}$ agonist protocol and trigged for final oocyte maturation with hCG. All patients received vaginal $P_{4}$ for luteal phase support. Dotted lines depict 6 , 14 , and $30 \mathrm{nmol} / \mathrm{l}$, respectively. (B) Daytime variations in mid-luteal serum $17-\mathrm{OH} \mathrm{P}_{4}$ in three women treated in the $\mathrm{GnRH}$ antagonist protocol and trigged for final oocyte maturation with a bolus of $\mathrm{GnRH}$ agonist. All patents received vaginal $P_{4}$ for luteal phase support in combination with one (patient\#5 and \#6) or two (patient \#7) boluses of hCG on the day of oocyte pick-up and 5 days later, respectively. Dotted lines depict 6 and 14 nmol/l.

The CL produces 17-OH $\mathrm{P}_{4}$, as well as, $\mathrm{P}_{4}$ during the luteal phase (13). However, the secretion pattern of the two steroids differs. Coinciding with the $\mathrm{LH}$ peak, an initial distinct $17-\mathrm{OH}$ $\mathrm{P}_{4}$ peak occurs reflecting the initial luteinisation and growth of the theca lutein cells-the luteal cell-line capable of 17$\mathrm{OH} \mathrm{P}_{4}$ synthesis (13). After 2-4 days of decline, the $17-\mathrm{OH}$ $\mathrm{P}_{4}$ levels increase again-now in parallel with $\mathrm{P}_{4}$ reaching a second peak during the mid-luteal phase, followed by a decrease toward the end of the luteal phase. In the natural cycle, the mid-luteal ratio of $17-\mathrm{OH} \mathrm{P}_{4} / \mathrm{P}_{4}$ is reported to be $10-20 \%$ $(13,23-26)$. We found a similar ratio of $\sim 10 \%$ in our cohort and this ratio did not change significantly with increasing levels of $\mathrm{P}_{4}$. The large inter-individual differences seen in the secretion pattern of $\mathrm{P}_{4}$ and $17-\mathrm{OH} \mathrm{P}_{4}$ underline that the CL function is highly individual, and that comparable values of $\mathrm{P}_{4}$ in individual patients may correspond to very diverse levels of 17-OH $\mathrm{P}_{4}$. Furthermore, three out of seven randomly chosen patients who participated in the daytime monitoring displayed severely reduced endogenous $17-\mathrm{OH} \mathrm{P}_{4}$ levels throughout the day (median levels 1.9-3.8 nmol/l). These concentrations are even lower than seen during the mid-luteal phase of the natural 
cycle $(\sim 6 \mathrm{nmol} / \mathrm{l})$ (18). Additionally, the very low serum 17 $\mathrm{OH} \mathrm{P}_{4}$ levels were accompanied by low serum $\mathrm{P}_{4}$ levels (36$55 \mathrm{nmol} / \mathrm{l})$. The exogenous vaginal $\mathrm{P}_{4}$ supplementation induces a serum $\mathrm{P}_{4}$ level of $\sim 30-40 \mathrm{nmol} / \mathrm{l}$, thus underlining that the abovementioned three patients had a severely diminished endogenous $\mathrm{P}_{4}$ secretion. This occurred although two of the patients had 17 and 19 follicles, respectively, on the day of trigger. Thus, the CL function is individual, and a large number of CLs do not necessarily warrant a high steroid output in the mid-luteal phase. Furthermore, it seems that a severely decreased mid-luteal $\mathrm{CL}$ function is not a rare finding following IVF treatment despite a sufficient trigger regimen and luteal phase support.

The biological effect of $17-\mathrm{OH} \mathrm{P}_{4}$ is not well-described. Whereas, $\mathrm{P}_{4}$ has a fundamental impact on the decidualization process (27), the maternal immunological adaption in early pregnancy (28) and the dampening of uterine contractions at the time of implantation (29), the endogenous $17-\mathrm{OH} \mathrm{P}_{4}$ has only very weak progestogen effects (30). The binding affinity of $17-\mathrm{OH} \mathrm{P}_{4}$ to both $\mathrm{P}_{4}$ receptors (PR-A and PR-B) is only $1 \%$ of that of $\mathrm{P}_{4}$. Furthermore, upon binding, the capacity of $17-\mathrm{OH} \mathrm{P}_{4}$ to activate subsequent gene expression is very low and only $\sim 0.12 \%$ of that of $\mathrm{P}_{4}(30)$. Thus, even though $\mathrm{P}_{4}$ and $17-\mathrm{OH} \mathrm{P}_{4}$ are structurally similar and are secreted in parallel from the CL, they seem to work in different ways. In serum, $\mathrm{P}_{4}$ is tightly bound to cortisol-binding protein (18\%) and loosely bound to albumin (80\%) whereas only $2 \%$ of $\mathrm{P}_{4}$ is unbound (free) $(24,31)$. The free form of $\mathrm{P}_{4}$ is available for diffusion out of capillaries, into cells where it exerts its function (32). A fraction of the secreted $\mathrm{P}_{4}$ and $17-\mathrm{OH} \mathrm{P}_{4}$ from the CL is transported directly to the uterus through a counter-current exchange mechanism from the utero-ovarian veins into the utero-ovarian arteries driven by a large concentration gradient $(33,34)$. This mechanism may function to secure a high biological steroid concentration from the site of production (the ovaries) directly to the target organ (the endometrium) $(34,35)$. Another fraction of secreted $\mathrm{P}_{4}$ and $17-\mathrm{OH} \mathrm{P}_{4}$ from the $\mathrm{CL}$ enters circulation directly via the ovarian veins, which terminate in the inferior vena cava (right) and the renal vein on the left (36). The binding affinity of $17-\mathrm{OH} \mathrm{P}_{4}$ to cortisol-binding protein (CBP) is much greater than that of $\mathrm{P}_{4}$ and close to that of cortisol (24). It can be speculated that $17-\mathrm{OH} \mathrm{P}_{4}$ acts by displacing $\mathrm{P}_{4}$ and cortisol from CBP, thereby increasing the free active hormone concentration locally in the ovarian veins. Thus, this mechanism will ensure a high, free $\mathrm{P}_{4}$ concentration facilitating the counter-current transport from the venous to the arterial vascular bed and hence, an increased direct transport of $\mathrm{P}_{4}$ to the endometrium.

It should be emphasized that natural, endogenous $17-\mathrm{OH} \mathrm{P}_{4}$ differs chemically and biologically from the synthetic progestin 17-OH $\mathrm{P}_{4}$ caproate (17-OHPC). The latter is a synthetic progestogen (compound with progesterone-like action) and is not produced endogenously (37). The 17-OHPC binds more avidly to the $\mathrm{P}_{4}$ receptor than natural $17-\mathrm{OH} \mathrm{P}_{4}$, eliciting a sustained and robust progestogen effect on the endometrium (30). Thus, 17-OHPC can be used as luteal phase support (IM administration) whereas monotherapy with natural $17-\mathrm{OH} \mathrm{P}_{4}-$ with a very weak direct progestogen effect-probably would be inefficient in terms of rescuing the luteal phase following IVF treatment.

From a clinical viewpoint, $17-\mathrm{OH} \mathrm{P}_{4}$ may be used as a direct biomarker for luteal phase function, as $17-\mathrm{OH} \mathrm{P}_{4}$ is not supplied as part of the luteal $\mathrm{P}_{4}$ supplementation regimen. Thus, the measured $17-\mathrm{OH} \mathrm{P}_{4}$ reflects the endogenous production predominantly from the $\mathrm{CL}$, as only a minor fraction $(\sim 0.5$ $\mathrm{nmol} / \mathrm{l}$ ) of circulating mid-luteal $17-\mathrm{OH} \mathrm{P}_{4}$ originates from the adrenal glands $(23,26)$.

Our findings of a non-linear association between $17-\mathrm{OH}$ $\mathrm{P}_{4}$ levels and the reproductive outcomes is in line with other studies examining luteal phase steroid profiles. Following frozenthawed embryo transfer, work by Yovich et al. (8) and Alsbjerg et al. (10) both showed a diminished chance of ongoing pregnancy if serum $\mathrm{P}_{4}$ was above or below a defined optimal $\mathrm{P}_{4}$ range. Similarly, in a previous paper using the present patient cohort, we found a consistently non-linear pattern describing the association between early and mid-luteal P4 levels and reproductive outcomes. Thus, suggesting that both low, as well as, high luteal $\mathrm{P} 4$ levels reduce the chance of a positive pregnancy outcome following fresh embryo transfer (9). In that study, $\mathrm{P}_{4}$ monitoring was performed during the early luteal phase (2-3 days following OPU) or in the mid-luteal phase $(\mathrm{OPU}+5)$. The same pattern emerged in this study, measuring serum $17-\mathrm{OH} \mathrm{P}_{4}$ on $\mathrm{OPU}+7$.

Taken together, the non-linear pattern between luteal steroid levels and reproductive outcomes seems to apply both to $\mathrm{P}_{4}$ and $17-\mathrm{OH} \mathrm{P}_{4}$, to different days in the luteal phase $(2,3,5$, or 7 days after OPU) and to both the fresh and frozen embryo transfer cycle (8-11). Furthermore, the above-mentioned studies all found a consistency in the absolute risk reduction (14-20 percentage points) below or above the defined $\mathrm{P}_{4}$ which is in line with our present results.

In this study, daytime monitoring of $17-\mathrm{OH} \mathrm{P}_{4}$ showed that patients with a diminished luteal phase function (17-OH $\mathrm{P}_{4}$ $<6 \mathrm{nmol} / \mathrm{l}$ ) displayed a constant $17-\mathrm{OH} \mathrm{P}_{4}$ pattern throughout daytime without any significant fluctuations in serum levels. Thus, measurement of luteal $17-\mathrm{OH} \mathrm{P}_{4}$ concentrations will accurately detect patients with low endogenous $17-\mathrm{OH} \mathrm{P} \mathrm{P}_{4}$ levels and, thus, a decreased corpus luteum function. In patients with higher 17- $\mathrm{OH} \mathrm{P}_{4}$ concentrations, fluctuations in serum 17- $\mathrm{OH} \mathrm{P}_{4}$ concentrations occur in a random fashion without any obvious common pattern between patients.

The possible clinical effect of serum fluctuations is demonstrated in patient \#7 (Figure 4). When measuring $17-\mathrm{OH} \mathrm{P} \mathrm{P}_{4}$ levels at 8.00 a.m., the patient would be classified in the optimal 17- $-\mathrm{OH}_{4}$ range between 6 and $14 \mathrm{nmol} / \mathrm{l}$. However, if measurements were performed at 12.00 p.m., she would be categorized in the $14.1-30 \mathrm{nmol} / \mathrm{l}$ group. Similarly, patient \#2 shift between 17-OH $\mathrm{P}_{4}$ group $14.1-30$ and $>30$ $\mathrm{nmol} / \mathrm{l}$ depending on the time of measurements. Thus, the figure demonstrates that when $17-\mathrm{OH} \mathrm{P}_{4}$ monitoring is done 7 days after OPU, there is a risk of misclassification of patients if serum $17-\mathrm{OH} \mathrm{P}_{4}>6 \mathrm{nmol} / \mathrm{l}$. The finding, that the magnitude of the 17- $\mathrm{OH} \mathrm{P}_{4}$ fluctuations depends on the $17-\mathrm{OH} \mathrm{P}_{4}$ concentration, is in total agreement with the $\mathrm{P}_{4}$ daytime variation on OPU +7 previously shown by our group (14). 
We monitored 17-OH $\mathrm{P}_{4}$ on $\mathrm{OPU}+7$ to explore whether the non-linear association between progestogen levels and reproductive outcome was still present at the time of implantation compared to earlier luteal measurements (2, 3 , or 5 days following OPU) (9). Based on the present results, this seems to be the case. Performing the luteal monitoring early in the luteal phase, allows for an intervention based on the results. Thus, better reproductive outcomes may be obtained by additional exogenous luteal $\mathrm{P}_{4}$ support to the low $\mathrm{P}_{4}$ or $17-\mathrm{OH}$ $\mathrm{P}_{4}$ group and by segmentation followed by subsequent embryo transfer in a frozen/thawed cycle in case of a high $\mathrm{P}_{4}$ or $17-\mathrm{OH}$ $\mathrm{P}_{4}$ level. In a clinical setting monitoring of $\mathrm{P}_{4}$ or $17-\mathrm{OH} \mathrm{P}_{4}$ on $\mathrm{OPU}+7$ is disadvantageous as the clinical consequence of a "too low" or "too high" progestogen level is limited. Thus, at this time of cycle, the embryo is already transferred and the effect of administering additional exogenous $\mathrm{P}_{4}$ during peri-implantation may be reduced compared to administration earlier in the luteal phase (38). Furthermore, in some IVF patients, peak levels of P4 and $17-\mathrm{OH} \mathrm{P} 4$ are seen already on day 5-6 and following this $\mathrm{P} 4$ and 17-OH P4 start to decrease. It could be hypothesized that some of the patients with low 17-OH P4 measured on day 7, had sufficient levels of 17-OH P4 earlier in the luteal phase and therefore are classified as "false low" on day 7. These patients could theoretically belong to a group with better pregnancy chance compared to patients with consistently low 17-OH P4 levels throughout the luteal phase. This misclassification of some of the patients could potentially affect the OR in the low $17-\mathrm{OH}$ $\mathrm{P} 4$ group and underestimate the effect of low 17-OH P4 on the chance of pregnancy.

Whether the 17- $\mathrm{OH} \mathrm{P}_{4}$ monitoring offers a clinical advantage compared to the more traditional $\mathrm{P}_{4}$ monitoring may be questioned. The 17-OH $\mathrm{P}_{4}$ does not seem to display a more stable luteal daytime pattern in patients with sufficient CL function compared to $\mathrm{P}_{4}$ (14). Furthermore, whereas the analytical performance of $\mathrm{P}_{4}$ immunoassays is generally high, the immunoassays available for the quantification of $17-\mathrm{OH} \mathrm{P}_{4}$ suffer from important analytical limitations $(39,40)$. The specificity of 17- $\mathrm{OH} \mathrm{P}_{4}$ measured by immunoassays is critically limited due to reduced reproducibility and cross reactivity with particularly $\mathrm{P}_{4}$ (40). To account for this, $17-\mathrm{OH} \mathrm{P}_{4}$ quantification must be performed using LC-MS/MS to obtain sufficient accuracy. This requires more manual work for the medical laboratory technician compared to a $\mathrm{P}_{4}$ quantification using standard immunoassays and this more than triples the expense per sample. Finally, as demonstrated by Figure 2A, some patients display a low midluteal 17- $\mathrm{OH} \mathrm{P}_{4}$ level even though the concomitant measured $\mathrm{P}_{4}$ level seems sufficient. This phenomenon may reflect an isolated defect in the function of the luteinized theca cells but a sufficient

\section{REFERENCES}

1. Csapo AI, Pulkkinen M. Indispensability of the human corpus luteum in the maintenance of early pregnancy. Luteectomy evidence. Obstet Gynecol Surv. (1978) 33:69-81. doi: 10.1097/00006254-197802000-00001

2. Humaidan P, Bredkjaer HE, Bungum L, Bungum M, Grondahl ML, Westergaard L, et al. GnRH agonist (buserelin) or hCG for ovulation
$\mathrm{P}_{4}$ output from the luteinized granulosa cells (13) and may lead to a misclassification of the patient.

The key strengths of the present study include its prospective design, the large cohort of patients and the systematic approach to the handling of confounding factors by use of Directed Acyclic graphs minimizing the risk of collider stratification (41). Furthermore, all patients received the same type and dose of vaginal $\mathrm{P}_{4}$ supplementation in the luteal phase ensuring a basis for comparison between patients. Furthermore, the participants included in the study were unselected broadening the generalizability of the findings.

In conclusion, this study shows for the first time that the chance of a live birth is reduced by $\sim 10$ percentage points below, but also above the defined optimal range for $17-\mathrm{OH}$ $\mathrm{P}_{4}$ measured on OPU+7. This finding supports the emerging evidence that the absolute concentrations of luteal $\mathrm{P}_{4}$ seem to affect the reproductive outcomes following IVF treatment. Based on the present study, luteal monitoring of $17-\mathrm{OH} \mathrm{P}_{4}$ levels alone does not seem to offer a better insight into the CL function compared to the monitoring of total $\mathrm{P}_{4}$ levels.

\section{AUTHOR CONTRIBUTIONS}

LT, PH, CA, and KE designed the study. LT drafted the manuscript and $\mathrm{UK}, \mathrm{CA}, \mathrm{KE}, \mathrm{MO}$ and $\mathrm{PH}$ all contributed to the interpretation of data and critically reviewed the manuscript. All co-authors participated in the conduction of the study and approved the final manuscript.

\section{FUNDING}

An unrestricted grant from Ferring Pharmaceuticals, Denmark, supported this study. Furthermore, grants from The Health Research Fund of Central Denmark Region, The Research Foundation of the Hospital of Central Jutland, The Research Foundation of Dagmar Marshall, The Research Foundation of A. P. Møller, The Research Foundation of Aase \& Ejnar Danielsen, The Research Foundation of Dir. Jacob Madsen \& Hustru Olga Madsen, The Research Foundation of Fam. Hede Nielsen and The Danish Medical Research Grant supported conducting this study. The providers of funding were neither involved in the conduction of the study nor in the writing of the scientific report.

\section{SUPPLEMENTARY MATERIAL}

The Supplementary Material for this article can be found online at: https://www.frontiersin.org/articles/10.3389/fendo. 2018.00690/full\#supplementary-material study. Hum Reprod. (2005) 20:1213-20. doi: 10.1093/humrep/deh765

3. Humaidan P, Bungum L, Bungum M, Yding Andersen C. Rescue of corpus luteum function with peri-ovulatory HCG supplementation in IVF/ICSI GnRH antagonist cycles in which ovulation was triggered with a GnRH agonist: a pilot study. Reprod Biomed Online (2006) 13:173-8. doi: 10.1016/S1472-6483(10)60612-8 
4. Humaidan P, Ejdrup Bredkjaer H, Westergaard LG, Yding Andersen C. 1,500 IU human chorionic gonadotropin administered at oocyte retrieval rescues the luteal phase when gonadotropin-releasing hormone agonist is used for ovulation induction: a prospective, randomized, controlled study. Fertil Steril. (2010) 93:847-54. doi: 10.1016/j.fertnstert.2008.12.042

5. Beckers NG, Macklon NS, Eijkemans MJ, Ludwig M, Felberbaum RE, Diedrich $\mathrm{K}$, et al. Nonsupplemented luteal phase characteristics after the administration of recombinant human chorionic gonadotropin, recombinant luteinizing hormone, or gonadotropin-releasing hormone $(\mathrm{GnRH})$ agonist to induce final oocyte maturation in in vitro fertilization patients after ovarian stimulation with recombinant follicle-stimulating hormone and GnRH antagonist cotreatment. J Clin Endocrinol Metab. (2003) 88:4186-92. doi: 10.1210/jc.2002-021953

6. Petersen JF, Andersen AN, Klein BM, Helmgaard L, Arce JC. Luteal phase progesterone and oestradiol after ovarian stimulation: relation to response and prediction of pregnancy. Reprod Biomed Online (2018) 36:427-34. doi: 10.1016/j.rbmo.2017.12.019

7. Muasher S, Acosta AA, Garcia JE, Jones GS, Jones HW Jr. Luteal phase serum estradiol and progesterone in in vitro fertilization. Fertil Steril. (1984) 41:838-43. doi: 10.1016/S0015-0282(16)47895-7

8. Yovich JL, Conceicao JL, Stanger JD, Hinchliffe PM, Keane KN. Midluteal serum progesterone concentrations govern implantation rates for cryopreserved embryo transfers conducted under hormone replacement. Reprod BioMed Online (2015) 31:180-91. doi: 10.1016/j.rbmo.2015.05.005

9. Thomsen LH, Kesmodel US, Erb K, Bungum L, Pedersen D, Hauge B, et al. The impact of mid-luteal serum progesterone levels on live birth rates - A prospective study of 602 IVF/ICSI cycles. Human Reprod. (2018). 33:1506-16. doi: 10.1093/humrep/dey226

10. Alsbjerg. Thomsen LH, Elbaek HO, Laursen R, Povlsen BB, Humaidan P. Progesterone levels on pregnancy test day after hormone replacement therapy frozen embryo transfer cycles are related with the reproductive outcome - An observational cohourt study and mini review. Reprod BioMed Online (2018) 17:676-83. doi: 10.1016/j.rbmo.2018.08.022

11. Labarta E, Mariani G, Holtmann N, Celada P, Remohi J, Bosch E. Low serum progesterone on the day of embryo transfer is associated with a diminished ongoing pregnancy rate in oocyte donation cycles after artificial endometrial preparation: a prospective study. Hum Reprod. (2017) 32:243742. doi: 10.1093/humrep/dex316

12. Kofinas JD, Blakemore J, McCulloh DH, Grifo J. Serum progesterone levels greater than $20 \mathrm{ng} / \mathrm{dl}$ on day of embryo transfer are associated with lower live birth and higher pregnancy loss rates. J Assist Reprod Genet. (2015) 32:1395-9. doi: 10.1007/s10815-015-0546-7

13. Strott CA, Yoshimi T, Ross GT, Lipsett MB. Ovarian physiology: relationship between plasma LH and steroidogenesis by the follicle and corpus luteum; effect of HCG. J Clin Endocrinol Metab. (1969) 29:1157-67. doi: 10.1210/jcem-29-9-1157

14. Thomsen LH, Kesmodel US, Andersen CY, Humaidan P. Daytime variation in serum progesterone during the mid-luteal phase in women undergoing in vitro fertilization treatment. Front Endocrinol. (2018) 9:92. doi: 10.3389 /fendo.2018.00092

15. ALPHA Scientists in Reproductive Medicine, ESHRE Special Interest Group Embryology. Istanbul consensus workshop on embryo assessment: proceedings of an expert meeting. Reprod Biomed Online (2011) 22:632-46. doi: 10.1016/j.rbmo.2011.02.001

16. Gardner DK, Lane M, Stevens J, Schlenker T, Schoolcraft WB. Blastocyst score affects implantation and pregnancy outcome: towards a single blastocyst transfer. Fertil Steril. (2000) 73:1155-8. doi: 10.1016/S0015-0282(00)00518-5

17. Humaidan P, Polyzos NP, Alsbjerg B, Erb K, Mikkelsen AL, Elbaek HO, et al. GnRHa trigger and individualized luteal phase hCG support according to ovarian response to stimulation: two prospective randomized controlled multi-centre studies in IVF patients. Hum Reprod. (2013) 28:2511-21. doi: 10.1093/humrep/det249

18. Aedo AR, Pedersen PH, Pedersen SC, Diczfalusy E. Ovarian steroid secretion in normally menstruating women. II. The contribution of the corpus luteum. Acta Endocrinol. (1980) 95:222-31. doi: 10.1530/acta.0.0950222

19. Howards PP. An overview of confounding Part 1: the concept and how to address it. Acta Obstet Gynecol Scand. (2018) 97:394-9. doi: $10.1111 /$ aogs.13295
20. Howards PP. An overview of confounding Part 2: how to identify it and special situations. Acta Obstet Gynecol Scand. (2018) 97:400-6. doi: 10.1111 /aogs. 13293

21. Bosch E, Labarta E, Crespo J, Simon C, Remohi J, Jenkins J, et al. Circulating progesterone levels and ongoing pregnancy rates in controlled ovarian stimulation cycles for in vitro fertilization: analysis of over 4000 cycles. Hum Reprod. (2010) 25:2092-100. doi: 10.1093/humrep/deq125

22. Venetis CA, Kolibianakis EM, Bosdou JK, Lainas GT, Sfontouris IA, Tarlatzis $\mathrm{BC}$, et al. Estimating the net effect of progesterone elevation on the day of hCG on live birth rates after IVF: a cohort analysis of 3296 IVF cycles. Hum Reprod. (2015) 30:684-91. doi: 10.1093/humrep/deu362

23. Usuki S, Kondoh K, Kubo T. Plasma endothelin and LH-RH, LH, FSH, prolactin, progesterone, 17alpha-hydroxyprogesterone, estrone, 17betaestradiol, delta4-androstenedione, testosterone, active renin, angiotensinII and ANP levels in blood and LH, estrone and 17beta-estradiol and pregnanediol levels in urine of normal cycling women. $J$ Cardiovasc Pharmacol. (2000) 36(5 Suppl. 1):S421-7.

24. Andersen CY. Possible new mechanism of cortisol action in female reproductive organs: physiological implications of the free hormone hypothesis. J Endocrinol. (2002) 173:211-7. doi: 10.1677/joe.0.1730211

25. Mikhail G, Allen WM. Ovarian function in human pregnancy. Am J Obstet Gynecol. (1967) 99:308-12. doi: 10.1016/S0002-9378(16)34535-5

26. Parker CR Jr, Bruneteau DW, Greenblatt RB, Mahesh VB. Peripheral, ovarian, and adrenal vein steroids in hirsute women: acute effects of human chorionic gonadotropin and adrenocorticotrophic hormone. Fertil Steril. (1975) 26:87788.

27. Young SL, Lessey BA. Progesterone function in human endometrium: clinical perspectives. Semin Reprod Med. (2010) 28:5-16. doi: 10.1055/s-0029-1242988

28. Druckmann R, Druckmann MA. Progesterone and the immunology of pregnancy. J Steroid Biochem Mol Biol. (2005) 97:389-96. doi: 10.1016/j.jsbmb.2005.08.010

29. Fanchin R, Ayoubi JM, Righini C, Olivennes F, Schonauer LM, Frydman R. Uterine contractility decreases at the time of blastocyst transfers. Hum Reprod. (2001) 16:1115-9. doi: 10.1093/humrep/16.6.1115

30. Attardi BJ, Zeleznik A, Simhan H, Chiao JP, Mattison DR, Caritis $\mathrm{SN}$, et al. Comparison of progesterone and glucocorticoid receptor binding and stimulation of gene expression by progesterone, 17-alpha hydroxyprogesterone caproate, and related progestins. Am J Obstet Gynecol. (2007) 197:599.e1-7. doi: 10.1016/j.ajog.2007.05.024

31. Mendel CM. The free hormone hypothesis: a physiologically based mathematical model. Endocr Rev. (1989) 10:232-74. doi: 10.1210/edrv-10-3-232

32. Rosner W. Sex steroids and the free hormone hypothesis. Cell (2006) 124:4556; author reply 456-7. doi: 10.1016/j.cell.2006.01.026

33. Bendz A, Lundgren $\mathrm{O}$, Hamberger L. Countercurrent exchange of progesterone and antipyrine between human utero-ovarian vessels, and of antipyrine between the femoral vessels in the cat. Acta Physiol Scand. (1982) 114:611-6. doi: 10.1111/j.1748-1716.1982.tb07032.x

34. Cicinelli E, de Ziegler D. Transvaginal progesterone: evidence for a new functional 'portal system' flowing from the vagina to the uterus. Hum Reprod Update (1999) 5:365-72. doi: 10.1093/humupd/5.4.365

35. Albrecht ED, Pepe GJ. Source and regulation of 17 alphahydroxyprogesterone during baboon pregnancy. Biol Reprod. (1984) 31:471-9. doi: 10.1095/biolreprod31.3.471

36. Paulsen F. Sobotta - Atlas of Human Anatomy. Baltimore, MD: Elsevier Health Sciences (1994).

37. Romero R, Stanczyk FZ. Progesterone is not the same as 17alphahydroxyprogesterone caproate: implications for obstetrical practice. Am J Obstet Gynecol. (2013) 208:421-6. doi: 10.1016/j.ajog.2013.04.027

38. Aslih N, Ellenbogen A, Shavit T, Michaeli M, Yakobi D, Shalom-Paz E. Can we alter pregnancy outcome by adjusting progesterone treatment at mid-luteal phase: a randomized controlled trial. Gynecol Endocrinol. (2017) 33:602-6. doi: 10.1080/09513590.2017.1298742

39. Patton PE, Lim JY, Hickok LR, Kettel LM, Larson JM, Pau KY. Precision of progesterone measurements with the use of automated immunoassay analyzers and the impact on clinical decisions for in vitro fertilization. Fertil Steril. (2014) 101:1629-36. doi: 10.1016/j.fertnstert.2014. 02.037 
40. Vogeser M, Parhofer KG. Liquid chromatography tandem-mass spectrometry (LC-MS/MS)-technique and applications in endocrinology. Exp Clin Endocrinol Diabetes (2007) 115:559-70. doi: 10.1055/s-2007981458

41. Suttorp MM, Siegerink B, Jager KJ, Zoccali C, Dekker FW. Graphical presentation of confounding in directed acyclic graphs. Nephrol Dial Transplant. (2015) 30:1418-23. doi: 10.1093/ndt/gfu325

Conflict of Interest Statement: LT received an unrestricted research grant from Ferring Pharmaceuticals to support this work. $\mathrm{PH}$ received unrestricted research grants from MSD, Merck, and Ferring Pharmaceuticals, as well as, honoraria for lectures from MSD, Merck, and Gedeon Richter outside of this work. USK received honoraria for lectures from MSD and Ferring Pharmaceuticals outside of this work. CA received unrestricted research grants from MSD, IBSA, and Ferring
Pharmaceuticals, as well as, honoraria for lectures from MSD and IBSA outside of this work.

The remaining authors declare that the research was conducted in the absence of any commercial or financial relationships that could be construed as a potential conflict of interest.

Copyright (C) 2018 Thomsen, Humaidan, Erb, Overgaard, Andersen and Kesmodel. This is an open-access article distributed under the terms of the Creative Commons Attribution License (CC BY). The use, distribution or reproduction in other forums is permitted, provided the original author(s) and the copyright owner(s) are credited and that the original publication in this journal is cited, in accordance with accepted academic practice. No use, distribution or reproduction is permitted which does not comply with these terms. 